\title{
篩骨紙狀板，傾斜度二就 テ
}

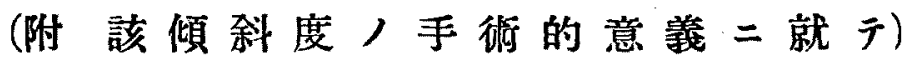

Dr. Ryo Takahashi u. Dr. Masashi Isbizuka:

Ober dem Neigungswinkel des Lamina papylacea ethmoidales.

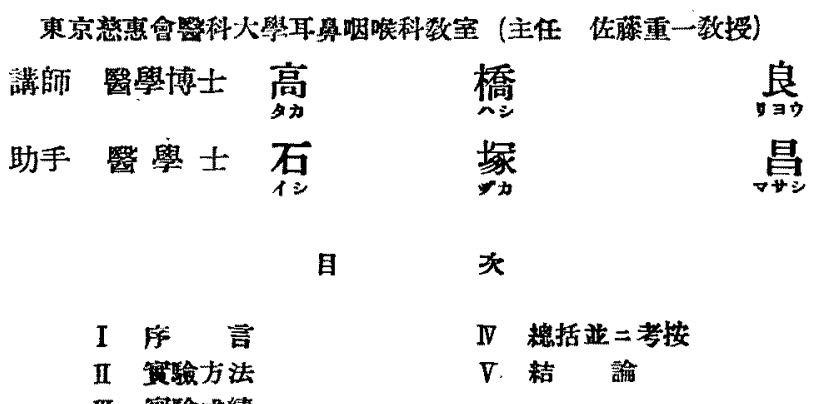

I 序

言

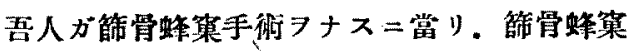
ノ内部檴造 7 知悉スベキハ忽諭ノ事ナルモ. 其

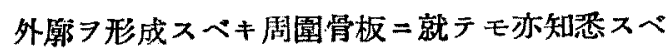
キ八更二必要事ナル事ト思惟ス。

蓋シ篮骨蜂窠手術＝於テ八其內部フ形成スベキ 各蜂寞ハそア總テ除去スべキモノナルモ。外遊 ヨ形成スベキ周園骨壁八之ヨ全損塲七又樣保 存セネバナラヌ故ナリ。

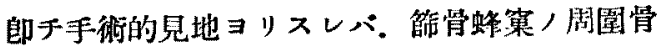
板隔壁八蜂案自身／內部桠造ヨリ重要性アリト 云ハザルべカラズ。

郎千䇻骨蜂菓，队壁．上壁。外壁，下壁等，解 剖學的狀態ア豫メ了解シ置ク事八缝ダ重要ナル モノト考へラル。 然ル二從來此篩骨蜂策, 外部 7 形成スべキ各骨 壁内内.内壁郎チ牭介側。上壁郎千頭蓋底.下 壁习構成スペキ各䗋策基板等二就テ八比较的詳
シク检絷サレ居ルニモ拘ラズ. 外壁郎チ紙狀板 二就テハ其構造, 單純ナル第メカ之二觸レタル モノ谌ダ少キフ認ムルナリ。

彼, 鼻科解剖學, 杽斗タリシZuckerkandl 成 畫二於テモ之二就テ極り簡單二䚡レタルノ $\bar{i}=$ シテ.吻諭手術的意䉝，如キ攧こラレザルナリ。 Zuckerkandl 以後二於テモ節骨蜂案, 左右徑. 前後徑等ヨ計测セル者八數氏存スル。. 余等 手術二有意揫ナリト認メタル紙狀板，傾科度二 就テ检シタルモノ八之ヨ見ス。

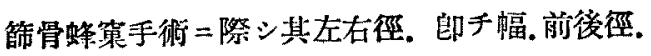
郎チ骨行等 傾科度郎于如何ナル倾キ具合ニテ存スルヤヨ知 ル八節骨蜂菓, 外壁 7 平滑ナラシムル際二最モ 便宜ナルモノト思惟スルナリ。

殊二紙狀板卜界影門部卜，移行部。源骨部附近 等 7 完全二處置スル際二痛感スル所ニシテ。紙 
狀板, 名ノ示ス如ク斯ク।如ク菲薄ナル骨板 損稘せザル様手街》進行七ンニ八凡ユル角店ヨ リ之ア觀察シツ、行つ事必要ニシテ. 余等ハ此

\section{II 實 驗 方 法}

\section{A 計测材料及ビ計測保件}

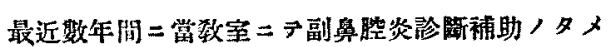
撮影をシ「レ」線「フィルム」中次，修件二適セN モノ $\neq 100$ 板選出をり。

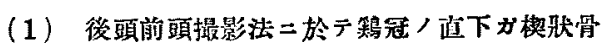
小巽卜大體一致シ箱板が一洎線上二撮影サレタル如 キ₹'。

（2）後远スル如ク後頭前頭撮影法二於テ䄳状板

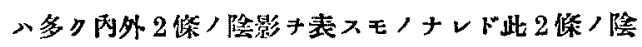
影ガ計測二必要ナル程度二明瞭二撮影サレタルモ

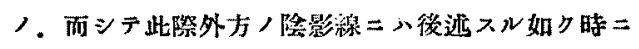
重揫性キ表ハス 2 本乃至 3 本二撮影サル、コトアル モ. 斯クノ如キ際ニ 明瞭且ツ長大ナル方キ方二远 ブル後解狀板传ノ計算二用七タリ。

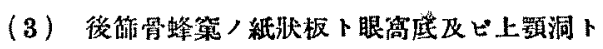
人境界ガ一點二合シタル場所。毁チ篐骨蜂笨第三基 板ノ外側基點が明睹二撮影サレタルモノ，此曾合點

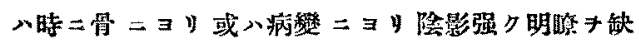

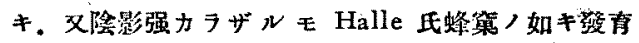
良好ナル時不明ナルコトアท。

以上ノ如キ條件二適スル「レ」線「フィルム」中二

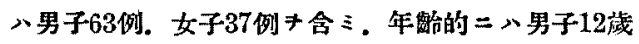

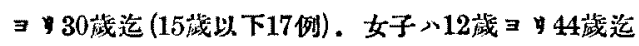
(15㖪以下 6 例 $)$ ナリ。

\begin{tabular}{|c|c|c|c|c|c|c|}
\hline & & 第 & 1 & 表 & & \\
\hline 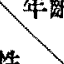 & $1 \sim 1$ & $\sim 20$ & $1 \sim 2$ & $6 \sim 30$ & $1 \sim 3$ & $41 \sim 45$ \\
\hline 男. & 17 & 27 & 7 & 8 & 0 & 0 \\
\hline 女 & 6 & 9 & 12 & 6 & 2 & 2 \\
\hline
\end{tabular}

(B) 計 测 万 法

(1) 粈爿板角二就 7

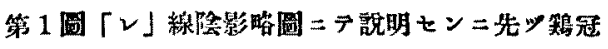

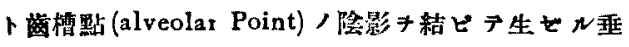

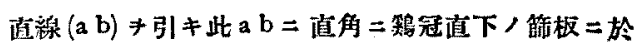

紙㕱板倾斜度 7 其重要ナルーツ人/䚋默トシテ取 上ゲそヨ以下述ブルガ如キ「レントダン」寫真 上ヨリ檢索シタルナリ。

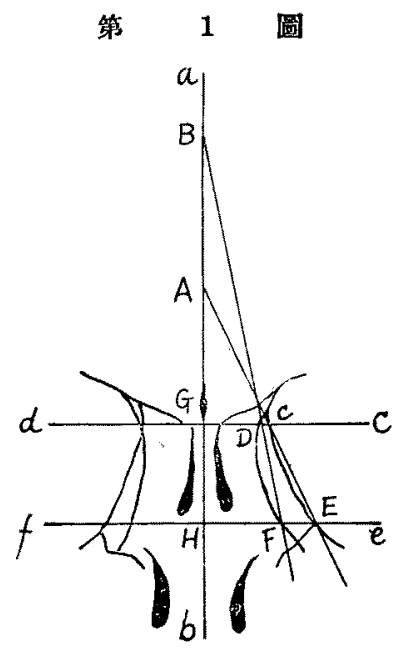

ト夜ハル點占トス。

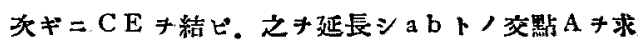
メ. 此噱二生ズル角 E A H キ後箱狀板角卜命名ス。 蓋シ本角度八後渻骨蜂窠ノ紙狀板ノ垂直線二對スル

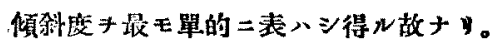
同栐こシテ角 F B H *作ע之キ前紙狀板角卜命名 ‥

以上ノ如キ前後ノ紙状板角キ計湘センニへ三角法 方式 $\equiv$ 次如如求メタy。

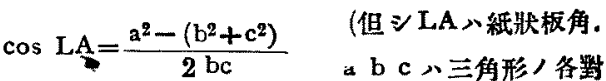

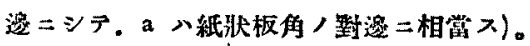

斯クシテ得タル前後紙状板角子紘計學的二算出七 \%。

（2）紙狀板 形恶二就

上派ノ如ク紙狀板角二就テ計測スルト共二。併を テ紙狀板ノ前後陰影キ形態的二觀察セり。

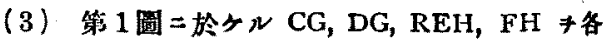

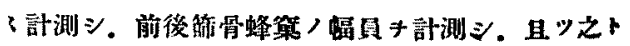

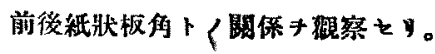
III 寞 驗成 續 
（1）前紙状板角，正員二就テ：

上述ノ如クンテ前後紙状板角キ計算入ル卜，後紙

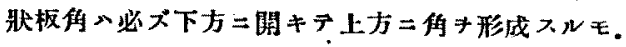
前絓扸板角二於テハ之ガ下方二開キテ上方 $=$ 角キ形 成スル埸合ト，上方二關キテ下方二角形成スル場 合卜ノ2種つル＼cjkstart見ル。

依ツテ之キ便宜上前兠，下方二開キテ上方二角キ作

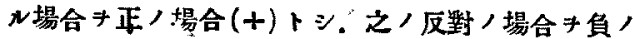
場合 (一) ト規定スベシ。

今嘪驗例 100 例中，正角*检スル二元ノ如シ。

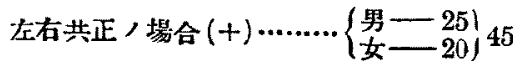

右右共負 場合 $\left\{\begin{array}{l}\text { 男 }-281 \\ \text { 女- }-12,40\end{array}\right.$

片侧正 $ニ シ テ$ 他侧证㨁線二本行… $\left\{\begin{array}{l}\text { 男—- } 3 \\ 女-1\end{array}\right\} 4$

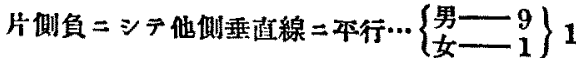

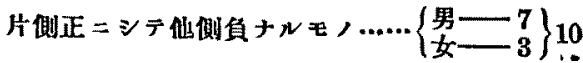

第 2 圆 前紙狀板角 正/場合 (+) 負/場合(一)

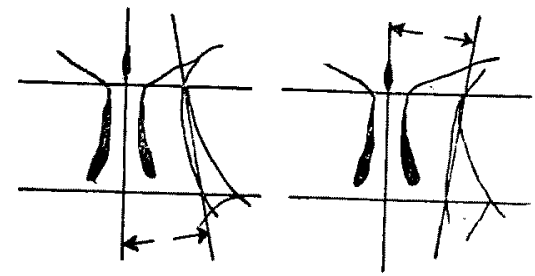

（2）前䋐狀板你/更均值

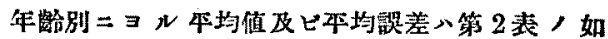

第 2 表 男

子

\begin{tabular}{|c|c|c|c|c|}
\hline 侧 年階 & $11 \sim 15$ & $16 \sim 20$ & $21 \sim 25$ & $26 \sim 30$ \\
\hline 右 & $\begin{array}{r}-2.58 \pm 3.52 \\
+3.23 \pm 1.32 \\
\end{array}$ & $\begin{array}{l}-4.07 \pm 2.04 \\
+6.15 \pm 3.46\end{array}$ & $\begin{array}{r}-4.72 \pm 2.16 \\
+5.24 \pm 0.87\end{array}$ & $\begin{array}{r}-3.77 \pm 0.93 \\
+10.22 \pm 5.42 \\
\end{array}$ \\
\hline te & $\begin{array}{r}-3.09 \pm 1.88 \\
+3.59 \pm 2.25 \\
\end{array}$ & $\begin{array}{r}-3.85 \pm 2.01 \\
+6.38 \pm 2.79 \\
\end{array}$ & $\begin{array}{r}-5.92 \pm 1.21 \\
+5.71 \pm 1.06 \\
\end{array}$ & $\begin{array}{r}-4.75 \pm 1.40 \\
+10.31 \pm 5.11 \\
\end{array}$ \\
\hline
\end{tabular}

註 : 但シ角度ノ前ニ+*附シタルハ正ノ場合ニシテーキ附シタルハ負ノ場合ナッ。以下之二準ズ。 女 子

\begin{tabular}{|c|c|c|c|c|c|c|}
\hline 㑡 年階 & $11 \sim 15$ & $16 \sim 20$ & $21 \sim 25$ & $26 \sim 30$ & $31 \sim 35$ & $41 \sim 45$ \\
\hline 右 & $\begin{array}{r}-4.16 \pm 1.69 \\
+5.30 \pm 1.69 \\
\end{array}$ & $\begin{array}{r}-4.27 \pm 1.19 \\
+4.06 \pm 0.69 \\
\end{array}$ & $\begin{array}{r}-3.20 \pm 0.50 \\
+5.41 \pm 1.03 \\
\end{array}$ & $\begin{array}{l}-4.89 \pm 1.36 \\
+4.90 \pm 1.75 \\
\end{array}$ & +4.42 & $\begin{array}{r}-10.78 \\
+11.63 \\
\end{array}$ \\
\hline 左 & $\begin{array}{r}-2.25 \pm 0.29 \\
+4.57 \pm 0.42\end{array}$ & $\begin{array}{r}-3.83 \pm 0.78 \\
+4.94 \pm 1.16\end{array}$ & $\begin{array}{l}-5.18 \pm 0.91 \\
+4.11 \pm 0.51\end{array}$ & $\begin{array}{l}-2.03 \\
+3.95 \pm 1.56\end{array}$ & $\begin{array}{r}-2.00 \\
+4.92\end{array}$ & $\begin{array}{r}-3.03 \\
+9.50\end{array}$ \\
\hline
\end{tabular}

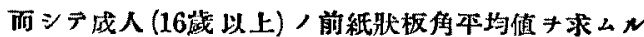
=炎ノ如

$$
\text { 男 }\left\{\begin{array}{l}
\text { 右伹 }\left\{\begin{array} { l } 
{ - 4 . 1 8 \pm 0 . 4 6 } \\
{ + 7 . 2 0 + 0 . 6 6 }
\end{array} \text { 女右側 } \left\{\begin{array}{l}
-5.78 \pm 0.70 \\
+6.97 \pm 0.96
\end{array}\right.\right. \\
\text { 大側 }\left\{\begin{array} { l } 
{ - 4 . 8 4 \pm 0 . 2 7 } \\
{ + 7 . 1 3 \pm 0 . 8 3 }
\end{array} \text { 子 } \left\{\text { 左側 } \left\{\begin{array}{l}
-3.21 \pm 0.84 \\
+5.44 \pm 0.34
\end{array}\right.\right.\right.
\end{array}\right.
$$

(3) 後紙狀板解平均㨁

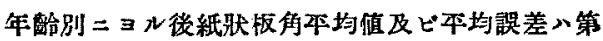
3 表! 如シ。

$$
\text { 第 } 3 \text { 表男年 }
$$

\begin{tabular}{|c|c|c|c|c|}
\hline 侧 & $11 \sim 15$ & $16 \sim 20$ & $21 \sim 25$ & $26 \sim 30$ \\
\hline 年䧃 & $32.49 \pm 1.99$ & $27.40 \pm 1.52$ & $33.54 \pm 1.73$ & $29.82 \pm 2.97$ \\
\hline 右 & $31.95 \pm 1.45$ & $27.54 \pm 1.36$ & $33.85 \pm 2.17$ & $30.26 \pm 2.32$ \\
\hline
\end{tabular}

女

子

\begin{tabular}{|c|c|c|c|c|c|c|}
\hline 年階 & $11 \sim 15$ & $16 \sim 20$ & $21 \sim 25$ & $26 \sim 30$ & $31 \sim 35$ & $41 \sim 45$ \\
\hline 右 & $32.06 \pm 4.05$ & $32.96 \pm 2.02$ & $32.19 \pm 1.20$ & $28.46 \pm 1.63$ & 34.38 & 24.66 \\
\hline 有 & $29.22 \pm 2.99$ & $29.60 \pm 1.38$ & $30.90 \pm 1.87$ & $30.27 \pm 1.80$ & 31.32 & 30.74 \\
\hline
\end{tabular}




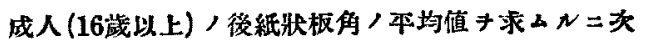
ノ如シ。

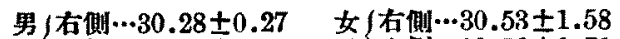

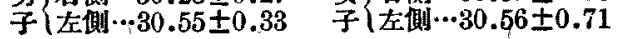
倘木上表二於テ $\mathrm{n}_{1} \times \mathrm{n}_{2}$ Table 3 y年路卜紙狀板角

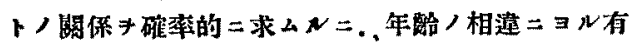
意ノ差認又得ス。

（4）前後紙狀板鿇，分布及ヒ最大最小角二就 本項キ表 $=ョ$ シテ示 第 4 表 前紙狀板角/分右

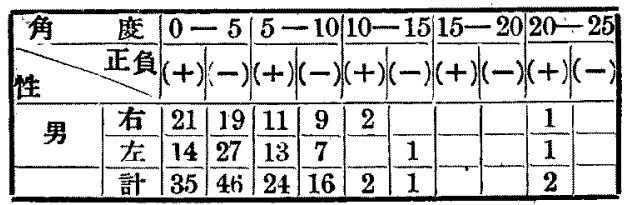

\begin{tabular}{|c|c|c|c|c|c|c|c|}
\hline \multirow{2}{*}{\multicolumn{2}{|c|}{ 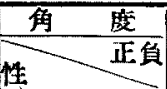 }} & \multicolumn{2}{|c|}{$0-5$} & \multicolumn{2}{|c|}{$5-10$} & \multicolumn{2}{|c|}{$10-15$} \\
\hline & & $(+)$ & $(-)$ & $(+)$ & $(-)$ & $(+)$ & $(-)$ \\
\hline \multirow{3}{*}{ 女 } & 右 & 11 & 10 & 9 & 4 & 2 & 1 \\
\hline & tr. & 14 & 12 & 8 & 3 & & \\
\hline & 計 & 25 & 22 & 17 & 7 & 2 & 1 \\
\hline
\end{tabular}

策 5 表 後紙狀板角 /分布

\begin{tabular}{|c|c|c|c|c|c|c|c|c|}
\hline$\sqrt{10}$ & $\begin{array}{c}10 \\
1 \\
15\end{array}$ & $\begin{array}{c}15 \\
1 \\
20\end{array}$ & $\begin{array}{c}20 \\
1 \\
25\end{array}$ & $\begin{array}{c}25 \\
1 \\
30\end{array}$ & $\begin{array}{c}30 \\
1 \\
35\end{array}$ & $\begin{array}{c}35 \\
1 \\
40 \\
\end{array}$ & \begin{tabular}{|c}
40 \\
1 \\
45 \\
\end{tabular} & $\begin{array}{c}45 \\
1 \\
50\end{array}$ \\
\hline 右 & & 5 & 11 & 13 & 19 & 8 & 5 & 1 \\
\hline 1 & & 3 & 8 & 19 & 18 & 9 & 3 & 2 \\
\hline & & & & & & & & \\
\hline
\end{tabular}

\begin{tabular}{|c|c|c|c|c|c|c|c|c|c|}
\hline 1 & & $\begin{array}{l}10 \\
15\end{array}$ & $\mid \begin{array}{c}15 \\
1 \\
20\end{array}$ & $\begin{array}{c}20 \\
1 \\
25\end{array}$ & $\begin{array}{c}25 \\
1 \\
30\end{array}$ & $\begin{array}{c}30 \\
1 \\
35\end{array}$ & $\begin{array}{l}35 \\
1 \\
40\end{array}$ & $\begin{array}{c}40 \\
1 \\
45\end{array}$ & $\begin{array}{c}45 \\
1 \\
50\end{array}$ \\
\hline 16 & & & 1 & 7 & 9 & 11 & 5 & 2 & 2 \\
\hline & & & 2 & 9 & 10 & 13 & 4 & 2 & \\
\hline & & & & 13 & 19 & 94 & & & \\
\hline
\end{tabular}

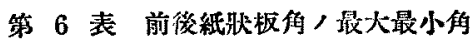

\begin{tabular}{|c|c|c|c|c|c|}
\hline \multicolumn{2}{|c|}{ 性 } & \multicolumn{2}{|c|}{ 男 } & \multicolumn{2}{|c|}{ 女 } \\
\hline 角 & & 最 大 & 最 小 & 最 大 & 最 小 \\
\hline 後 & 右 & 49.50 & 8 & 47.25 & 20.00 \\
\hline & tr & 48.33 & 6 & 42.13 & 15.28 \\
\hline 前 & 右 & 23.25 & -10.00 & 11.63 & -10.78 \\
\hline & 7 & 22.70 & -10.01 & 10.00 & -7.70 \\
\hline
\end{tabular}

（5）前後紙狀板角，關保

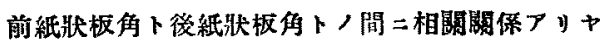
否ヤ二就テ之

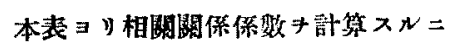

$$
r=\frac{\Sigma \mathrm{fd}^{\prime} \times \mathrm{d}^{\prime} \mathrm{y}-\mathrm{nw} \times \mathrm{wy}}{\mathrm{n} 6 \times 6 \mathrm{y}}
$$

第 7 表

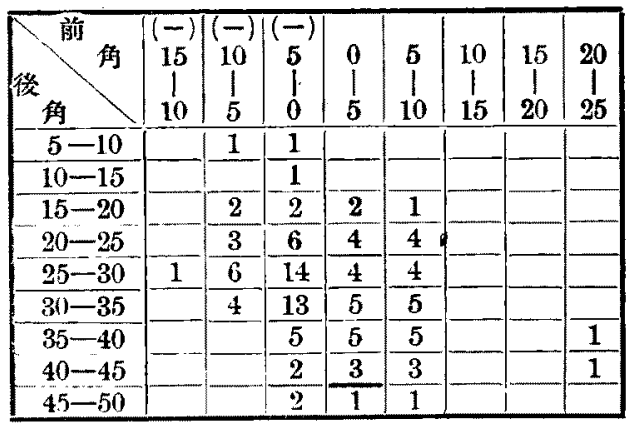

ヨリ $\mathrm{r}=0.083 \pm 0.09=テ$ 相閣關㛊入密接ナアズ. タメ二媵紙狀板角ノ大トナルニツレ前紙狀板角モ大 トナルト八硼シ得ザルモ，凡у後紙狀板角小小ナル

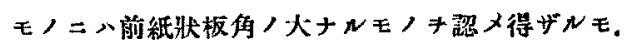
前紙狀板角ノ小ナルモノ二八後紙狀板角/大ナ $N$ モ , 認又得儿八注目二值 負角ノ火卜ナル二從七小トナルモノ卜假定入)。

（6）朋側紙狀板角，對照性

问一症例二於々ル左右紙爿板角ハ大體相似性 ノナレドモ。併シ非相似性ノモノモ相虽二存入。

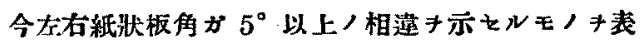
二示 $x=$ 第 8 表/如 \%。

\section{第 8 表}

\begin{tabular}{|c|c|c|c|}
\hline 此較 & 性 & 男 & 女 \\
\hline 右 $>$ 左 & 後 & 9 & 8 \\
\hline & 前 & 4 & 4 \\
\hline 左 $>$ 右 & 後 & 8 & 3 \\
\hline
\end{tabular}

即于男子二於テ八後紙状板角二於テ17例，前紙狀板 角二於于5例. 女子二於テン後二於テ11例. 前二於 テ 6 例 ニシテ. 男子二於テ八後 $26.9 \% \pm 5.6$. 前 八7.9\%士3.4. 女子 $=テ ハ$ ハ後ハ $29.7 \% \pm 7.5$. 前へ $16.0 \% \pm 6.0=$ テ 5 以上相趡々ル非相似性ノモノ 相當認入。決シテ非對昭ノ少カタザルキ知ルナ、。

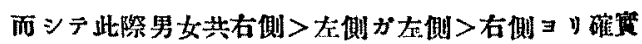

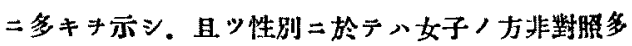
キモ。破率的二へ有意義ノ差キ認メザリキ。

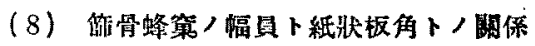

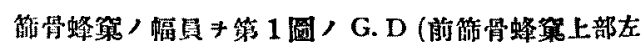

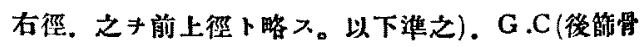

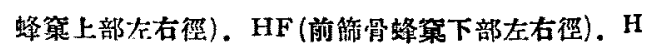




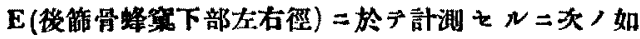
キ成镂得名。

之キ表二示ス二第 9 表ノ如シ。

第 9 落

\begin{tabular}{|c|c|c|c|c|c|}
\hline \multicolumn{2}{|c|}{ 性湢 } & $\begin{array}{l}\text { 肖直侕 } \\
(\mathrm{GD})\end{array}$ & 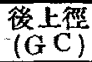 & $\begin{array}{l}\text { 前下咝 } \\
(\mathrm{H} \mathrm{F})\end{array}$ & 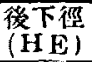 \\
\hline \multirow{2}{*}{ 男 } & 右 & $1.31 \mathrm{~cm}$ & 1.61 & 1.49 & 2.32 \\
\hline & $F_{r}$ & 1.44 & 1.65 & $1 . \overline{45}$ & 2.28 \\
\hline \multirow{2}{*}{ 女 } & 右 & 1.41 & 1.53 & 1.49 & 2.17 \\
\hline & 左 & 1.36 & 1.56 & 1.38 & $2 . \overline{34}$ \\
\hline
\end{tabular}

即チ後下征〉後上徑>前下徑〉前上位ナル關你キ示 シ且ッ男子ハ女子ョり倯、幅展キ*示シタり。

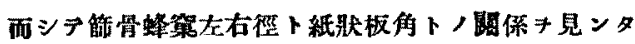
メ. 便宜上前節骨蜂黛二於々 $N$ 上下，左右亚，平均

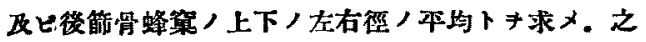
等卜前後紙狀板角卜，關你 $\neq$ 求么ル二，前紙状板角

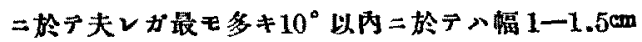
モ／最モ多》。男子二於アン1.5cm干超へタルモ ノモ相當つ、後紙狀板角二於テメ夫レが最モ多キ $25 \sim 35^{\circ}=$ 於テハ1.5〜2 $\mathrm{mm}=$ 㫳スルモノ最モ多キ キ示シタy。而シテ角大ナレハ幅无大トナル如キ凡

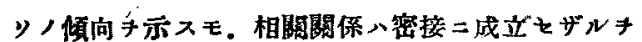
見N。

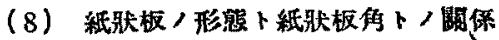

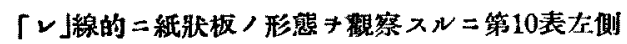
ノ如種々ナルモノキ認丈，其分布度八同表右侧

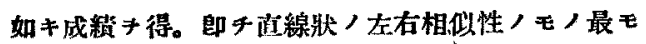

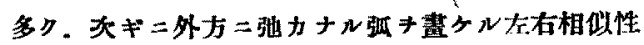

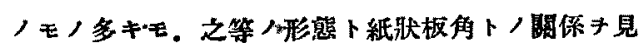
$N=$. 第 5 表ノ後紙狀板角分布度卜㱠ド同様ナル成 精キ示シ紙狀板ノ形㦔二ヨル特珠性キ示サザサ

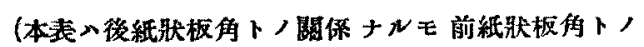

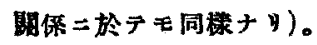

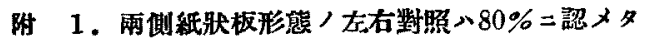
,

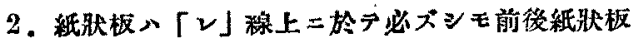
ノ2部ノミ線狀ノ㓌影キ現へスモノニハ非ズ。此事
第 9 表

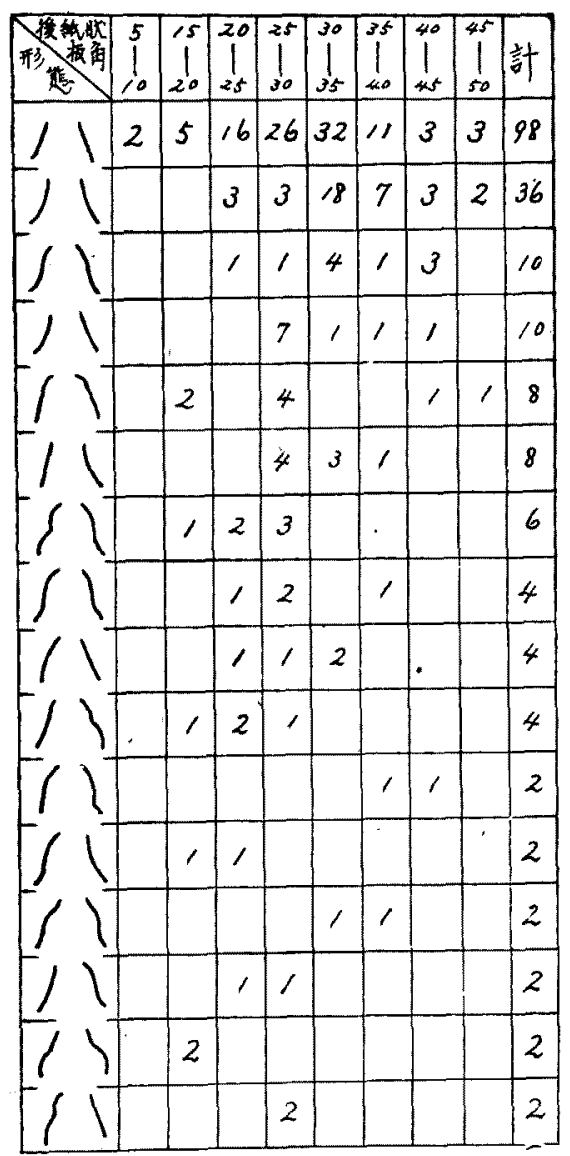

、撮影佟件ノ項二於テモ觸レタル所ニシテ、即チ後

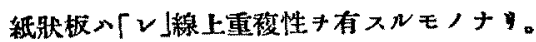

此重稜性二就テ检シタル所 $29 \%(100$ 例中) =磁見シ 得多 y。

而シア斯クノ如キ場合後紙状板角キ定ムルニン、列 ท明暸ナル㓌影キ現ハシタル方テ選どタルュト既迅 れル如シ。蓋シ院影ノ明カナルモノガョり樅深性 有スベレバナり。

\section{IV 總括並二考按}

1. 以上成績 7 要約スル ，偭斜度二八前紙狀板角，後紙狀板角， 2 種 7 計涮シ得ラレ，前紙狀板的二於テ八垂直線=對
シ上方二角 7 形成スル場合卜下方二形成スル場 合， 2 種 7 生ジ，前者 7 正觕トシ後者 7 負们卜

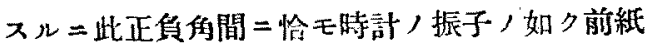


哆板们ハ伸縮スルモノナル事习知ル。 而シテ前紙狀板们，最大伯八 $(+) 23^{\circ}$ ，最小们 八(-) $12^{\circ}+ル$ ア以ラ此間＝伸縮スべキモ. 前 紙狀板何，分有度八 $(+)(-)$ 共 $10^{\circ}$ 以内 $=$ 多 ド大部分 $(96 \%)$ F有部木 $(+), 5^{\circ}$ 以内 $=$ $30 \%$ ．（一)， $5^{\circ}$ 以內 $=34 \%$ 有スルラ以ラ 全例， $2 / 3$ 八 $(+) 5^{\circ} \exists$ 的 $(-) 5^{\circ}$ 以内 $=$ 於于 schwanken スル事ヨ知ル(第 3 喝)。

第 3 圆 面シテ殘りノ大體 $1 / 3$ 八 $(t)$ $(+)\left(\right.$ 一)共 $5^{\circ} \sim 10^{\circ}$ 以內 ニ存スルモノシシテ $32 \%$ フ算シタリ。

抬木前紙狀板们, 平均值 八咸人 $=$ 於 $\overline{(}(+) 6.68^{*}$,

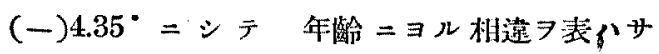
ズ。性ニヨル相違モ之ヨ表ハサザルモ男〉女， 傾向

2. 後紙狀板角 $=$ 於ラ最大 $49^{\circ}$ 最小 $6^{\circ} \Rightarrow$ 示シ其變異著明ナルモ，其分布度ハ 25 35・以

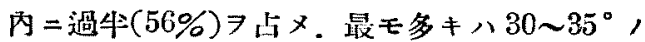
$30.5 \%$. 次八 25 30, $25.5 \%$. 次八 $20 \sim 25^{\circ}$ ，16\%。次心 $35 \sim 40^{\circ} ， 13 \%$ 示シタリ。 而シテ其平均值、 $30.5^{\circ}$ フ示シ。年路性 $=\exists ル$ 相遠 八垂直線 7 中心トシ左右 $=$ 大體 $30^{\circ}$ ，偭科 $\ni$ 示 ス 7 以テ 頂角 $60^{\circ}$ ，二等浿三角形郎于正三角 形ヨ形成スルモ，卜解スルラ得。

3. 前挠紙狀板角，關係ハ必ズ後紙狀板们> 前紙狀板角ニシテ前紙狀板角小ナルモ＝八 後紙狀板角ノ大ナルモノア認ムレドモ啳紙狀板 角ノ小ナルモノ =八前紙狀板角ノ大ナルモノ 認メ得ズ。從ツテ前紙永板角ノ大小 $\ni$ 以テ後紙 狀板觕ノ大小 7 律スル能ハザルナリ。
一般二紙狀板角八前後共大體相似性ノモノナレ ドモ。浒シ非相似性ナルモノモ決シテ稀ナラ ズ。即于左右側二於テ 5 以上，相遠习表八七 ルモノフ檢スル二後紬狀板朋二於テ八男 $27 \%$ 。 女 $30 \%=$ ，前紙狀板们=於テ八男 $81 \%$ ，女 16 $\%$ \%シ算シタリ。

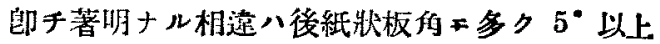
机遠スルモノ $71 / 3$ 前後二示シ。且ツ非相似性 八右側>左側 ヨ示シリ。

紙狀板们卜穊骨䗋案隔卜八關係二八特異ナルモ ，コ認メザリシモ，前紙狀板们＝於テ其 $10^{\circ}$ 以 内ノモノニ八幅 $1 \sim 1.5 \mathrm{~cm}$ ノモノ最モ多キフ認 メ，界子=於テ $(1.5 \mathrm{~cm}$ 以上ノモノモ相觉存シ。

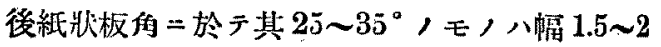
$\mathrm{cm} / モ ノ$ 最モ多キヨ認メタリ。

又紙狀板角卜紙狀板，形態卜，關係二於テ八 Zuckerkandl，言一ル紙狀板，直線的ナルモ ハト弛ク弧习畫クモノ、2 種卜ガ最モ多キヨ 示シ. 前者八 $49 \%=$. 後者八 $18 \%$ =存シ储七、 テ $67 \%$ 数フルモ. 形態的二八份木幾多ノモ) 人存在スルラ認メタリ。

而シテ形態，對照性 セルモノ キア認メタリ。

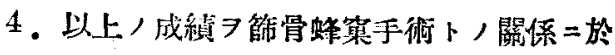
テ按ズルニ、術前「レ」線撮影ヨナシ以上/如 キ観察方法フ行フ時八街前手遇進行 指釬二甚 ダ至健ナルモノナリ。

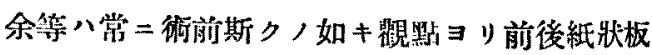
部，倾科度。倾科度／相促性。形態。形態/相 似性.「レ」線板上，重複性等 7 考虑シ。紙狀板

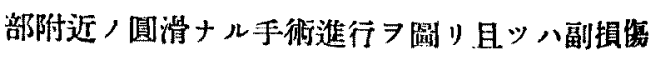
ア可及的除外シ得ッ・アルナリ。 
前紙彇板的八平均证们二於于八六體 $6.5^{\circ}$ 负角 二於テハ $4.5^{\circ}=$ シテ 全例, $2 / 3 八(+) 5^{\circ} \exists$ リ( - $5^{\circ}$ 以内 $=$ 振子狀 $=$ 伸縮スル 際手術時ニ八垂直卜看做シ手衔スベク。且ツ又 斯ク感ジ得ラル、モノナリ。

但シ「レ」線上前紙狀板的トシテ陰影习示ス部 分八解剖學的二八泿骨櫛直後，部分ニシテ 紙 狀板ハ之ョリ後部二至ルニッレ倾科度 以于 所謂前篣骨蜂案二屬ス几紙猋板部八前紙

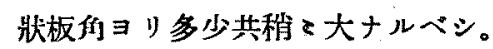
而シテ手辿 =際シテ此部ガ最モ骨壁菲薄ニシテ 破損シ易キラ以テ注意スベキナリ。即チ此部前 笠骨蚌巢, 幅. 陰影, 强サ(明瞭サ). 形態等 注意スベキナリ。

前紙狀板部ノ形態八後紙狀板部卜晎ナリ種タナ ル形ヨ表八ス事ナク殆ド總广直線的力. 弛々外

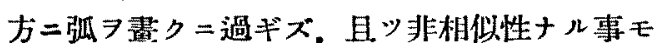
谌ダ稀ナルモノナリ。

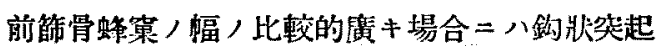

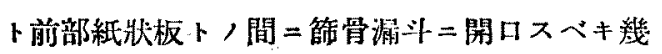
ツカ/蜂巢 7 有シ。手術二際シ钩狀突起 7 除キ タル跡 =モ紙狀板 $\ni$ 外壁卜スル䗋案 7 朋カ二認 メ得ルモノナレドモ(漏斗蛙窠)。前部籃骨䗋巢 ，䈪猍ク且ツ前紙狀板们ガ殊二頁仢 7 表ハスが

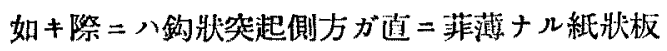
ア表ハス事アリ。斯クノ如キ際二八钩狀笑起其 モノフ除ク際ニテモ紙狀板 注意习裂ス。

余等八篩骨蜂筮手衔二際シテ可及的鉸匙，使用

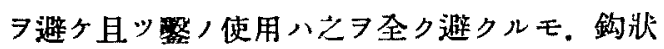

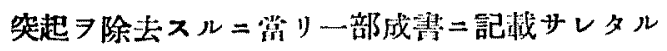

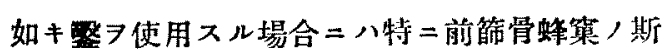
カル前紙狀板部卜，局所的關係 7 噘重二考虑 $=$
入レザルべカラザルベシ。

後紙狀板伯八 $25 \sim 35^{\circ}$ 以内 $=56 \%$ 有シ平均 $30^{\circ}$ フ示シタルガ. 今之外貌上ヨリ祭知セン 二第 4 圖ノ如ク鼻根部ヨリ鼻覃外浚二引ケル遖 楾が垂道線卜， 第 4 凅

ナス们い大體 $30^{\circ}$

内外トナル事多

シ。印于此兩側

二作レル三侀

八正三们トナル

故外罚二想定七

ル正三们, 兩側

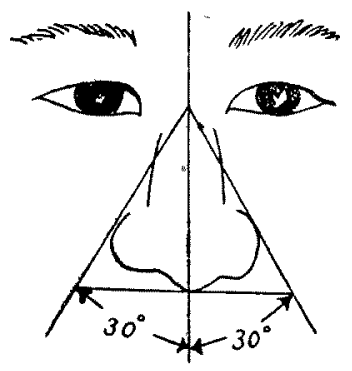

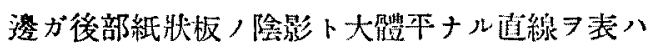
スモノト瑷想シ得ベシ。

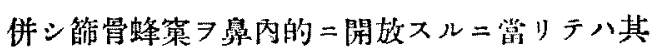
實際，倾科 $コ$ 小二見ユ儿事多キフ感ズ。蓋シ

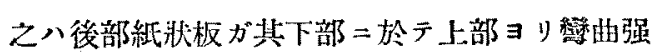
ク外方二弛キ弧フ畫キ易キ篇ナランカト考へラ ル:

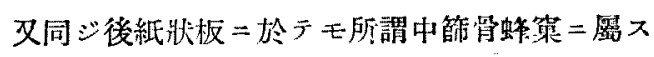

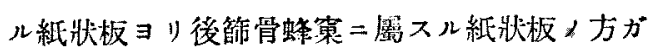
一般 $=$ 大ニシテ 此事八手術=際シ箱常感ゼラ ル、所ナリ。脌シ佾木後方二於少ル最後部紙狀 板或八楔狀部穊骨蜂案，紙狀板二於テ，其部紙 狀板倾斜，丽ビホナル事アリ。併シ乍ラシタ通 覽スル二紙狀板，倾斜八後方二到ル二從七浙次

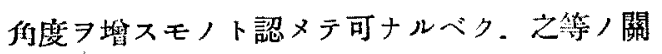
係八「レ」線陰影，重複性二於テ明カ二認メラ ル、所ナリ。

即チ後紙狀板的习表ハスベキ陰影が時二二重乃 至三重＝表ハレル事ニシテ。特二術前注意スベ

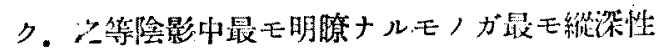
ヨ有スル事認識スベキナリ。 
又此陰影，重

第 5 圖

䙓性八後紙狀

板が眼窩上壁

一移行スル部

位二於テモ重

要性 7 表ハス

モノナリ

師于第 5 筒 $\mathrm{A}$

ノ如單純ナ

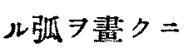
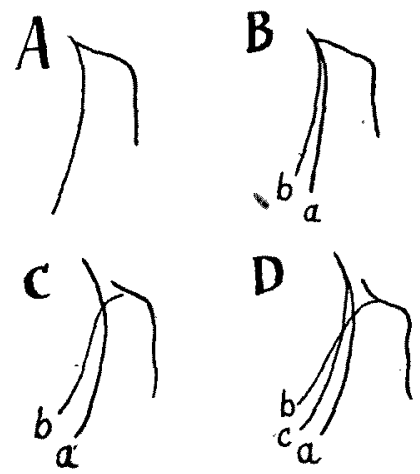

過ギザルモ，モ多數アレドモ。中=ハC，如ク 又 D，如ク二重。兰重二㓌影习表ハスモノ厂 1) 。

$\mathrm{B}=$ 於テハ $\mathbf{a b}$ 線共大體同形ニテ特異ナル事ナ

\section{V 結}

1. 挠頭前頭撮影法二ョル「レ」線竄真板 於テ一定，條件=適合スルモ，100枚（男63.

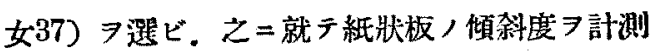
七リ.

2. 紙狀板八「レ」線寫畺上前紙爿板部卜後 紙矣板部ト二各隍影 7 表ハス。但シ後紙狀板， 夫レ八重襣性习表ハス事往々アリ。

3. 前紙狀板部, 傾刹度 7 前紙狀板你卜命名 シ之二就テ計測スル二，正解／場合卜負的人場 合卜习表ハシ。平均正伯ハ $6.68^{\circ}$. 負的ハ $4.35^{\circ}$ ナリ。

而シテ全例， $2 / 3$ 八正伯 $5^{\circ}$ ヨ少負们 $5^{\circ}$ ，間二 存スルヨ知レリ。
キモ. $\mathrm{C}$ 及 $\mathrm{D}=$ 於テハ $\mathrm{a}$ 線，外二特異ナル $\mathrm{b}$ 線 ヨ表ハス。

此 $\mathrm{b}$ 線，上部八內方二繁曲シ全體トシテ $\mathrm{S}$ 字狀 习畫クモ斯ク，如キ八前後，篩骨神經孔，間= 於テ且\%前後，穊骨神經孔ヨ結ビタル線上=於 テ>形二內側=入込么事ヨ表ハシ。此夕此部

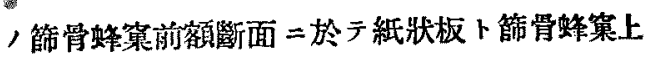

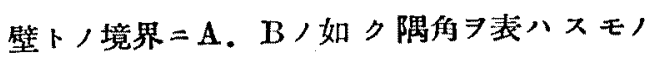
ト. C.D／如ク丸味习需ビ国滑二移行スルモ ,ト, 2 種フ生ズル事ヨ知ル。

此事算モ亦手衡時每掌遭遇スル所ノモノナリ。 郎于CD，如キ場合二八粘膜. Lamallen ansatz 等习除キ易キモ. A. B /如キ際ニハ之ヨ除り =困難 7 感ズ事多シ。

\section{䦂}

4. 後紙狀板部，倾刹度 7 後紙狀板伯卜命名 シ. えヨ計测スル 〜35 タ示シタリ。

5. 前後紙壯板何八大軆左右相似性ナレドモ 非相似性ナルモノモ相賞二認么。

6.「レ線上紙棜板, 形態八 $80 \%=$ 相似性 ア表ハシ直線的ナルモノ八最モ多ク $49 \%=$.

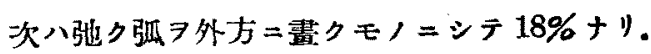
而シテ形態卜紙狀板们卜，間二ハ相關關係习謁 メズ。

7. 紙狀板伯及ビ紙状板，形態等，手㞱二際 シテ，意挛ア檢討シタル所，之等が少カラザル 手術的意義ヨ有スル事习認メタリ。

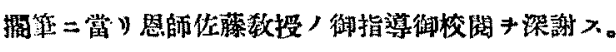

